\title{
THE INTERACTION OF HELA CELL HEAT DENATURED DNA WITH POLYGLUCOSE
}

I. L. Graves

Department of Epidemiology, School of Public Health University of Michigan, Ann Arbor, Michigan

Received July 10, 1967

The aqueous phase in phenol extracts of HeLa cells contain deoxyribonucleic acid (DNA), ribonucleic acid (RNA), and polyglucose (CHO), (Segovia et al., 1965). RNA reacts with the CHO and they coprecipitate in 20\% ethanol-saline solutions (Graves et al., 1967). Native DNA precipitates when the ethanol concentration is increased to $50 \%$. Although native DNA and CHO have equal buoyant densities in CsC1 (Segovia et al., 1965) and both precipitate in 50\% ethanol, the present data from analytical centrifugation indicate that these findings were not due to intermolecular bonding. In contrast, the following experiments denıonstrate that heat denatured DNA which is soluble in 50\% ethanol precipitates from this solution in the presence of CHO when the ratio of CHO/DNA approaches 2.5. The coprecipitation of CHO and DNA indicates that denatured DNA reacts with CHO, thus decreasing the solubility of the denatured DNA.

\section{MATERIALS AND METHODS}

HeLa cells were grown in monolayer cultures using Eagle's (Eagle, 1955) medium supplemented with $10 \%$ heat-inactivated calf serum. The cells were extracted with phenol (Colter et al., 1962). The RNA-CHO and DNA were successively precipitated in $20 \%$ and $50 \%$ ethanol solutions (Segovia et al. , 1965). The RNA was removed from the CHO by precipitation with trichloroacetic acid (Graves et al. , 1967) and the acid-soluble CHO was recovered by precipitating it with ethanol (66\%). DNA and CHO were dissolved in phosphate buffered saline (PBS) $0.005 \mathrm{M}, \mathrm{pH} 7.2$.

The DNA was quantitatively determined with the Burton (Burton, 1956) method and CHO with a diphenylamine reagent (Snell and Snell, 1953; Ackermann et al., 1964).

In analytical ultracentrifugation experiments the CHO, DNA and 
CHO-DNA were dissolved in PBS, pH 7.2, centrifuged at 20,000 RPM at $20^{\circ} \mathrm{C}$ in a standard cell using schlieren optics.

\section{RESULTS AND DISCUSSION}

CHO was added to native DNA and to DNA which was previously heat denatured $\left(100^{\circ} \mathrm{C}\right.$ for $15 \mathrm{~min}$.) in PBS and rapidly cooled. The mixtures (total volume $=1.5 \mathrm{ml}$.) were incubated 1 hour at $37^{\circ}$. Ethanol was carefully added to a final concentration of $50 \%$ and the solutions were held at $5^{\circ} \mathrm{C}$. After centrifugation at $1000 \mathrm{~g}$ for $10 \mathrm{~min}$. at $5^{\circ} \mathrm{C}$, super natant fluids were removed, precipitates dissolved in PBS and both analyzed for CHO and DNA. The total amounts of each polymer recovered from these two fractions are listed on Table 1. The CHO decreased the solubility of denatured DNA, whereas native DNA and $\mathrm{CHO}$ alone or in combination precipitated in 50\% ethanol solutions. Velocity sedimentation measurements were conducted to assess whether the precipitation of the CHO-DNA was due to intermolecular bonding.

TABLE 1

THE PRECIPITABILITY OF DENATURED DNA, NATIVE DNA, CHO AND COMBINATIONS THEREOF WITH 50\% ETHANOL ${ }^{a}$

\begin{tabular}{|c|c|c|c|c|}
\hline \multirow[b]{2}{*}{ Sample } & \multicolumn{2}{|c|}{ Supernatant } & \multicolumn{2}{|c|}{ Precipitate } \\
\hline & $\mathrm{CHO}$ & $\overline{\mathrm{DNA}}$ & $\overline{\mathrm{CHO}}$ & $\overline{\mathrm{DNA}}$ \\
\hline $\mathrm{CHO}$ & 45 & -- & 429 & -- \\
\hline$\triangle D N A^{b}$ & -- & 12.4 & -- & 0 \\
\hline DNA & -- & 2.9 & -- & 14.7 \\
\hline$\triangle D N A^{b}-C H O$ & 34.2 & 5.1 & 465 & 16.2 \\
\hline DNA - CHO & 51.3 & 0 & 408 & 22.4 \\
\hline
\end{tabular}

a. All values are total ug present.

b. DNA heated $100^{\circ} \mathrm{C} / 15 \mathrm{~min}$. Fraction increase $260 \mathrm{mu}$ absorption $A_{\Delta} / A_{0}=1.3$.

When centrifuged independently the CHO at $600 \mathrm{ug} / \mathrm{ml}$ and DNA at $370 \mathrm{ug} / \mathrm{ml}$ formed single peaks with $S_{20, W}$ values of 116 and 11.1 
respectively. When the CHO and DNA were combined and then centrifuged, two distinct peaks formed with $S_{20, W}$ values of 118 and 10.1 . These values are not considered significantly different from the values for the added components and indicate that no intermolecular bonding occurred.

Regarding denatured DNA, the amount of $\mathrm{CHO}$ required to precipitate it was determined by adding increasing amounts of $\mathrm{CHO}$ $(0$ to $120 \mathrm{ug})$ to $25 \mathrm{ug}$ of DNA. An equal volume of ethanol was added to the polymers which were dissolved in $1.5 \mathrm{ml}$. PBS. The solutions were held for 15 hours at $5^{\circ} \mathrm{C}$, centrifuged, and the precipitates and supernatant fluids analyzed for their content of DNA and CHO. Figure 1 illustrates the percent DNA precipitated and the ratio of CHO/DNA in the precipitates as affected by the ratios of CHO/DNA in the mixtures.

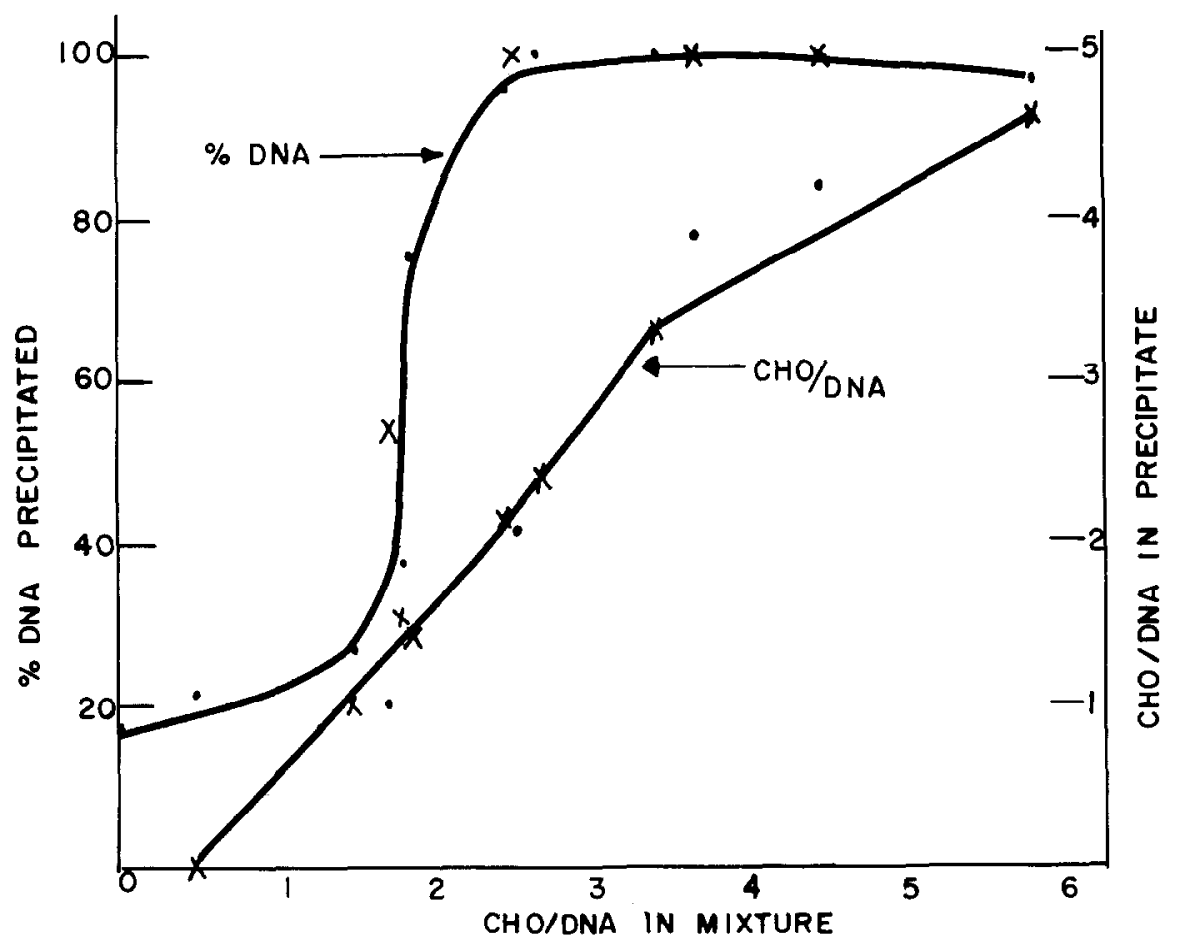

Figure 1. The solubility of heat denatured DNA in $50 \%$ ethanol solutions as affected by increasing amounts of polyglucose. Results from two experiments are distinguished by crosses and dots. 
To precipitate each ug of DNA, 2.5 ug CHO was required. Since the molecular weight of CHO from IIeLa cells has been determined to be about $3 \times 10^{6}$ (Sokol et al. , 1966), each molecule of CHO precipitated an amount of denatured DNA equivalent to an average molecular weight of approximately $1.2 \times 10^{6}$.

The intermolecular reaction of CHO-DNA may be explained on the basis of the availability of hydrogen bonding sites in denatured DNA. Most of these sites in native DNA are internally occupied in its helical structure thus reducing the capacity of the DNA to bond with the CHO. In contrast, denatured, single stranded DNA in heat denatured preparations would have reactive sites for bonding with the CHO. Of interest is the parallel finding that HeLa cell RNA reacts with CHO (Graves et al., 1967). In a biological context these interactions of $\mathrm{CHO}$ with nucleic acids may contribute to their intercellular protection, conformation, or regulation of expression.

\section{ACKNOWLEDGMENTS}

This investigation was supported by Public Health Service Research Grant No. AI-05876-03 from the National Institute of Allergy and Infectious Diseases.

\section{REFERENCES}

Ackermann, W.W., Sokol, F. and Brandau, A.J., Anal. Biochem., Burton, K., Biochem. J., 62, 315 (1.956).

Colter, J.S., Bran, R.A., and Ellen, K.A.O., Biochim. Biophys. Acta, 55, 31 (1962).

Eagle, H. , Exptl. Med., 102, 37 (1955).

Graves, I. L., Wahl, D., Davies, S.J., and Ackermann, W.W., Proc. Soc. Exptl. Biol. Med., submitted for publication.

Martinez-Segovia, Z. , Sokol, F., Graves, I. L., and Ackermann, W. W. , Biochim. Biophys. Acta, 95, 329 (1965).

Snell, F.D. and Snell, C.T., Colorimetric Method of Analysis, 3rd Edition, Vol. 3, 312, Van Nostrand, N. Y. (1953).

Sokol, F., Graves, I. L., and Ackermann, W. W., Biochim. Biophys. Acta, $112,74(1966)$. 